\title{
ZBAWCZE POŚREDNICTWO CHRYSTUSA W MYŚLI PAULA TILLICHA
}

\author{
CHRIST'S REDEMPTIVE MEDIATION \\ IN THE THOUGHT OF PAUL TILLICH
}

\begin{abstract}
A b stract. The question of the redemptive mediation of Christ is one of the key issues in dogmatic theology. One of the thinkers who presented the original concept of soteriology in modern times was Paul Tillich. This article presents his theory. In the first step, Tillich's views on the question of historical Jesus will be presented. Then the concept of salvation as a victory over the conditions of existence will be analyzed. Finally, the issue of redemptive mediation in paschal events will be discussed. The conducted analyzes lead to the conclusion that it is impossible to separate Christology from soteriology, and it is also impossible to build theology without using the category of mediation.
\end{abstract}

Keywords: Paul Tillich; Christology; mediation; soteriology, historical Jesus.

W klasycznej teologii centralne miejsce zajmuje osoba Chrystusa Pośrednika i dokonane przez Niego dzieło zbawienia człowieka i świata. Nie inaczej jest w myśli Paula Tillicha, choć niektóre jego ujęcia są oryginalne i dalece odbiegają od tych utrwalonych w chrześcijańskiej tradycji. Niniejszy artykuł stanowi analizę soteriologicznej myśli Tillicha w kluczu kategorii pośrednictwa. Na początku trzeba omówić bardzo istotny współcześnie problem, jakim jest relacja między postacią historycznego Jezusa a Chrystusem Zbawicielem. W ujęciu Tillicha problem ten znajduje dość radykalną i wyrazistą odpowiedź, która rzutuje także na myślenie o pośrednictwie Chrystusa. Dalej trzeba będzie przeanalizować, na czym polega w istocie zbawienie człowieka, jakiego dokonuje Jezus Chrystus. Ostatecznie trzeba

Dr Marcin WalcZaK - Katolicki Uniwersytet Lubelski Jana Pawła II, absolwent Wydziału Teologii, samodzielny referent w Biurze Regionalnej Inicjatywy Doskonałości; adres do korespondencji: Al. Racławickie 14, 20-950 Lublin; e-mail: marwal8@wp.pl; ORCID: https://orcid.org/ 0000-0002-8189-6392. 
będzie zwrócić uwagę na wydarzenia śmierci i zmartwychwstania Chrystusa w interpretacji Paula Tillicha.

\section{JEZUS HISTORII A CHRYSTUS ZBAWICIEL}

Mówiąc o pośrednictwie zbawczym w odróżnieniu od ontycznego, ma się zazwyczaj na myśli to, czego Chrystus w swoim życiu dokonał dla zbawienia człowieka i świata. W dawnych schematach teologicznego myślenia, zwłaszcza na Zachodzie, odwoływano się w tym względzie przede wszystkim do męki, śmierci i zmartwychwstania Jezusa. Tak ograniczona perspektywa soteriologiczna ma najczęściej swoje źródła w myśli Anzelzma z Canterbury i jest często obecna zwłaszcza w myśli protestanckiej. Obecnie dostrzega się, idąc choćby za dawnymi intuicjami Ojców Kościoła i franciszkańskich teologów średniowiecza, że całe życie Jezusa jest zbawienne, całą swoją historią Jezus zbawia człowieka i świat. Wydarzenia paschalne są szczególnym ukoronowaniem i spełnieniem tego zbawczego procesu, proces ten jednak obejmuje całe życie Jezusa. Sam Tillich nie poświęca aż tak wiele uwagi temu, co Chrystus dokonał w swojej Passze jako takiej. Bardziej koncentruje się na całym życiu Jezusa, które jest przełamaniem tragicznej sytuacji człowieka, jest zwycięstwem nad grzechem. W związku z tym soteriologia autora wymaga rozrachunku z problemem historyczności Jezusa. Znana kwestia, którą zwykło się określać jako problem Jezus historii-Chrystus wiary, znajduje swoje konkretne rozwinięcie w myśli Tillicha. Czy historia Jezusa, skoro jej dokładne poznanie wydaje się bardzo trudne i dyskusyjne, może być istotna dla ludzkiego zbawienia? Czy koncepcja Chrystusa Zbawiciela ma w ogóle coś wspólnego z historycznymi szczegółami życia Jezusa z Nazaretu?

Czasy Tillicha ujmuje się zwykle jako drugi etap rozwoju poszukiwań historycznego Jezusa. Pierwszoplanowym bohaterem tego okresu był Rudolf Bultmann, znany egzegeta protestancki. Twierdził on, że Nowy Testament należy poddać demitologizacji, to znaczy odrzucić wszystko to, co jest mityczną „naroślą" w opisywanych wydarzeniach ${ }^{1}$. Na pytanie, co pozostaje po takim procesie i co można uznać za rdzeń historyczny przekazu ewangelicznego, Bultmann odpowiadał prosto: Nic, ale to nie szkodzi. Podstawą teologii i chrześcijaństwa jest sam przekaz Ewangelii, nie zaś jego histo-

\footnotetext{
${ }^{1}$ Por. Rudolf Bultmann i Karl Jaspers, Problem demitologizacji, tłum. Dawid Kolasa, Tomasz Kupś i Maciej Pawlicki (Toruń: Wydawnictwo Naukowe UMK, 2015), 95.
} 
ryczny fundament czy jego brak. To samo dotyczy Jezusa historycznego szczegóły z Jego życia nie mają faktycznie żadnego znaczenia dla teologii. Nie należy więc zrażać się niemożliwością ich poznania. Oczywiście przeciwnicy tak radykalnej postawy natychmiast próbowali dowodzić, że Bultmann myli się i można wskazać historyczną podstawę narracji ewangelijnej. Tillich natomiast zdaje się stać bardziej po stronie Bultmannowskiego radykalizmu, z pewnymi jednak zastrzeżeniami. Przede wszystkim Tillich twierdzi po prostu, że: „Badania historyczne nie mogą ani położyć fundamentu pod wiarę chrześcijańską, ani też pozbawić jej tego fundamentu"². Teolog ten zauważa, że „chrześcijaństwo nie opiera się na akceptacji jakiejś historycznej powieści; zasadza się na świadectwie dawanym mesjańskiemu charakterowi Jezusa przez ludzi, którzy nie byli w ogóle zainteresowani napisaniem biografii Mesjasza"3.

Gdyby szczegółowe wyniki badań historycznych miały być fundamentem i źródłem wiary, byłaby ona skazana na nieustanne dociekania i modyfikacje. Wiara polegałaby na przekonaniu, że dane opowieści lub cała Ewangelia mają poparcie w historycznych faktach. Można zatem powiedzieć, że w takiej optyce wiara jest uznaniem za prawdziwe jakichś wydarzeń, dzięki wsparciu historycznych badań, a może czasem na przekór braku takiego wsparcia. Taką wiarą mogłyby zachwiać wyniki wykopalisk archeologicznych lub nowe odkrycia filologiczne ${ }^{4}$.

Tymczasem wiara nie jest — jak można przeczytać w książce Dynamika wiary — „aktem poznania o niskiej oczywistości”. Nie można widzieć jej jako jakiegoś przekonania o prawdziwości jakichkolwiek prawd, w tym wypadku - faktów historycznych, które miały się dokonać w czasach biblijnych. Prawdziwa wiara jest czymś znacznie większym i głębszym. Według Tillicha jest ona stanem absolutnego zaangażowania, pochwycenia przez troskę ostateczną. Pojęcie troski ostatecznej jest jednym z terminów technicznych myśli Tillicha. Definiowanie wiary właśnie jako troski ostatecznej oznacza, że jest ona całkowitym zaangażowaniem człowieka, które jest skierowane $\mathrm{w}$ stronę ostatecznego spełnienia ${ }^{6}$. W tym znaczeniu wiara nie jest czymś z porządku naturalnego poznania, w którym w grę wchodzą argumenty i kontrargumenty, debata, naukowe poszukiwania. Fundament wiary jest trwały i pewny, choć nie ma on żadnej naoczności, właściwej wynikom

\footnotetext{
${ }^{2}$ Paul Tillich, Teologia systematyczna, t. 2, tłum. Józef Marzęcki (Kęty: Antyk, 2004), 109.

${ }^{3}$ Ibid., 102.

${ }^{4}$ Por. ibid..

${ }^{5}$ Paul Tillich, Dynamika wiary, tłum. Adam Szostkiewicz (Poznań: W Drodze, 1987), 53.

${ }^{6}$ Por. ibid., 31.
} 
badań naukowych. Prawdziwym fundamentem wiary jest po prostu spotkanie z żywym Bogiem. Ewangelia jest fundamentem w tym właśnie sensie, że to spotkanie rodzi i do niego prowadzi. Nie jest natomiast tak, że jakieś badania historyczne dotyczące ksiąg Ewangelii mogą taką wiarą zachwiać. Jest ona od takich poszukiwań zupełnie niezależna. Ponadto badania nad historycznym Jezusem nie dawały w czasach Tillicha, a i nie dają dzisiaj żadnych jednoznacznych wyników. Każdy autor rekonstruuje postać Jezusa w sposób, który jemu samemu wydaje się odpowiedni. Brakuje zgody co do nawet podstawowych faktów z życia Jezusa i Jego faktycznego nauczania. Tillich powołuje się w tym względzie na Alberta Schweitzera, który dokonał krytyki popularnych rekonstrukcji postaci Jezusa historycznego ${ }^{7}$. Autor ten twierdził, że w odmalowywane portrety Jezusa badacze niejako wkładają więcej siebie samych niż realnych, konkluzywnych wniosków historiograficznych. Dlatego również w kwestii samego Jezusa historycznego nie można oprzeć wiary na wynikach badań historycznych. W kluczu myśli Tillicha można by dodać, że to bardzo dobrze. Brak jednoznacznych wyników badań egzegetyczno-historycznych przypomina, że wiara musi opierać się na czymś innym.

Jeśli Chrystus jest Zbawicielem, a Jego egzystencja jest zbawienna dla człowieka, wydawać by się mogło, że znajomość szczegółów tej egzystencji jest jednak konieczna. Jak wiara może abstrahować od historycznego wymiaru życia Jezusa, jeśli chce właśnie Jego nazywać Chrystusem i Zbawicielem? Takie pytania stawiał już Tillichowi jeden z jego krytyków, katolicki teolog George Henry Tavard $^{8}$. Przede wszystkim trzeba powiedzieć, że zdaniem Tillicha Jezus jest Zbawicielem jako Chrystus, a więc chodzi o pojawienie się w Nim Nowego Bytu' ${ }^{9}$ Samo pojawienie się Nowego Bytu, czyli - mówiąc inaczej — zbawienia, jest po prostu czymś, czemu osoba wierząca w Chrystusa nie może zaprzeczyć. $Z$ wewnętrznej perspektywy wiary chrześcijańskiej faktyczne istnienie Jezusa jest, zdaniem Tillicha, niezaprzeczalne. Nowy Byt nie może być z tej perspektywy zaprzeczony przez jakiekolwiek wyniki badań historycznych. Gdyby w życiu Jezusa nie objawił się Nowy Byt, nie miałaby sensu wiara chrześcijańska. Jeśli jednak ma ona sens, jeśli ludzie naprawdę doświadczają zwycięstwa nad egzystencjalnym wyobcowaniem, to Jezus Chrystus opisany w Ewangeliach naprawdę jest

\footnotetext{
${ }^{7}$ Por. Tillich, Teologia systematyczna, t. 2, 99-100.

${ }^{8}$ Por. George Henry Tavard, Paul Tillich and the Christian Message (New York: Scribner, 1962), 82.

${ }^{9}$ Por. Paul Tillich, The New Being (New York: Charles Scribner's Sons, 1955), 103.
} 
Zbawicielem ${ }^{10}$. Istotny jest zatem raczej ewangeliczny wizerunek Jezusa Chrystusa niż sam Jezus z Nazaretu jako postać historyczna ${ }^{11}$. Żadna historyczna jednostka nie może być wszak źródłem zbawienia sama z siebie. Chodzi zatem o to, co Bóg objawił i uczynił ludzkości za pośrednictwem Jezusa, nie zaś o to, kim był historyczny Jezus jako taki. Innego zdania jest jeden z polemistów teologa, Moody Smith, który utrzymuje, że nie wolno $\mathrm{w}$ teologii pomijać jej historycznego fundamentu ${ }^{12}$. Zdaniem zaś Tillicha nie trzeba zrażać się wieloznacznością wyników badań historycznych Jesus Quest $^{13}$. Sami zaś badacze i niektórzy ich odbiorcy popełniają niekiedy ten właśnie błąd, że Jezusa jako postać historyczną biorą za sedno i przedmiot wiary chrześcijańskiej. Gdyby rzeczywiście tak się sprawy miały, wówczas faktycznie ustalenie prawdy na temat Jezusa historycznego byłoby rozstrzygające dla teologii. W rzeczywistości potrzebny jest natomiast pewien dystans do prowadzonych badań.

Wydaje się słusznym zgodzić się zasadniczo w tym punkcie z Tillichem. Badania nad Nowym Testamentem i Jezusem historii są bardzo ważne także z perspektywy teologii. Mogą rzucić światło na wiele szczegółowych kwestii, zwłaszcza chrystologicznych, dlatego autor pisze, że „badania historyczne użyczyły teologii systematycznej narzędzia do zajmowania się chrystologicznymi symbolami Biblii" ${ }^{14}$. Mogą także być ożywcze dla wiary chrześcijańskiej. Nie mogą jednak zachwiać fundamentem wiary, ani stać się jej nową podstawą ${ }^{15}$. Punktem wyjścia dla Kościoła jest Jezus Chrystus, nie zaś historyczny Jezus ${ }^{16}$. Można jednak odnieść wrażenie, że Tillich tak bardzo chce uniknąć uzależnienia wiary od wyników badań historycznych, że aż wpada w przeciwną skrajność. Da się odczuć u teologa wręcz brak zainteresowania wobec poszukiwań Jezusa historycznego. Tymczasem wzięcie

\footnotetext{
${ }^{10}$ Pojęcie „Zbawiciela” i „zbawienia” jest dla Tillicha ściśle związane z wizją całkowitego uzdrowienia, wyzwolenia człowieka. Por. Tillich, The New Being, 45; Paul Tillich, "Redemption in Cosmic and Social History", w: Main Works/Hauptwerke. VI, red. Gert Hummel (Berlin / New York: De Gruyter, 1992), 276.

${ }^{11}$ Por. Tillich, Teologia systematyczna, t. 2, 110-111.

${ }^{12}$ Por. Dwight Moody Smith, Jr., „The Historical Jesus in Paul Tillich's Christology”, The Journal of Religion 46, nr 1 (1966): 131-147.

${ }^{13}$ Por. Tillich, Teologia systematyczna, t. 2, 105.

${ }^{14}$ Por. ibid.

${ }^{15}$ Wybitny katolicki badacz z nurtu Jesus Quest sformułował tę kwestię następująco: „The historical Jesus, while not the object or essence of faith, must be an integral part of modern theology". John Paul Meier, A Marginal Jew. Rethinking the Historical Jesus, t. 1 (New York: Doubleday, 1991), 198-199.

${ }^{16}$ Por. Tillich, The New Being, 98.
} 
pod uwagę tychże badań rzuca często nowe światło na problematykę chrystologiczną, jak pokazują choćby przykłady takich myślicieli, jak Edward Schillebeeckx czy Hans Küng, którzy swoje chrystologie zbudowali na podstawie badań historycznych nad osobą Jezusa.

Jeśli historia Jezusa nie ma sama $\mathrm{w}$ sobie rozstrzygającego znaczenia dla wiary w Chrystusa, można zapytać o to, czy sytuacji nie zmieniłoby nawet nieistnienie Jezusa. Można sobie bowiem wyobrazić, że naukowcy ogłaszają, iż przedstawiona $\mathrm{w}$ Ewangeliach postać jest produktem religijnej wyobraźni mieszkańców Palestyny z I wieku. Tenże eksperyment myślowy jest niezwykle istotny, niezależnie od faktu, że dzisiaj badacze są zasadniczo zgodni co do faktycznego istnienia historycznej postaci Jezusa z Nazaretu. Dawniej podnoszono, co prawda, tezę o tym, że postać Chrystusa jest wyłącznie wyspekulowanym mitem, twierdzenia negujące istnienie Jezusa pojawiały się jeszcze w propagandowej literaturze epoki marksizmu ${ }^{17}$. Dziś nawet badacze nieprzychylni chrześcijaństwu są zgodni co do tego, że Jezus z Nazaretu faktycznie istniał.

Zakładając jednak, że nieistnienie Jezusa jest teoretyczną możliwością, trzeba zmierzyć się z pytaniem, czy taka możliwość nie zagraża wierze. O ile szczegóły historycznej egzystencji Jezusa nie mają, według Tillicha, znaczenia dla wiary, o tyle pozostaje otwartym pytanie, czy sam fakt egzystencji Chrystusa ma takie znaczenie. Czy jest do wyobrażenia, że chrześcijaństwo funkcjonowałoby jako oparte wyłącznie na samym micie? Jeśli Jezus nigdy by nie istniał, czy można byłoby być chrześcijaninem? Na to pytanie Tillich odpowiada przecząco. Choć wiara nie opiera się na historycznych wydarzeniach, jest jednak powiązana z pewną faktycznością. Jeśli nie nastąpiło Wcielenie, jeśli Logos rzeczywiście nie objawił się przez życie konkretnego człowieka - nie pojawił się Nowy Byt. Nie może być mowy o zbawieniu i o chrześcijaństwie, czyli uczestnictwie w tym zbawieniu. Jeśli więc wiara nie zakłada żadnych historycznych pewników na temat Jezusa, zakłada jednak samo Jego istnienie. Tillich zaznacza nawet, że samo imię Jezusa nie jest zagwarantowane przez wiarę. Jeśli świadectwa są $\mathrm{w}$ tym względzie mylące, jest możliwe, że Chrystus nie miał na imię Jezus ${ }^{18}$. Choć

\footnotetext{
${ }^{17}$ Historyczność Jezusa zaczęto negować dopiero w XIX wieku (Bruno Bauer, David Strauss). Następnie tego typu tezy pojawiały się u badaczy związanych z marksizmem i wiązały się raczej $\mathrm{z}$ zapałem propagandowym, niż z naukową rzetelnością. Obecnie insynuacje tego rodzaju są radykalnie odrzucane, nawet przez tak sceptycznie nastawionych badaczy jak Bart Ehrman zob. jego Did Jesus Exist? The Historical Argument for Jesus of Nazareth (San Francisco: HarperCollins, 2012).

${ }^{18}$ Por. Tillich, Teologia systematyczna, t. 2, 110.
} 
to absurdalna idea, trzeba przyznać, że taki fakt nie mógłby zmienić istoty chrześcijańskiego orędzia. Tak więc jedyne, co wiara gwarantuje w sprawie historycznego Jezusa, to to, że istniał. Nie chodzi przy tym o fakt istnienia człowieka o imieniu Jezus lub jakichś specjalnych cechach. Rzecz w tym, że wiara zakłada uczestnictwo w Nowym Bycie, który rzeczywiście pojawił się na tym świecie ${ }^{19}$.

Wiara gwarantuje więc swoją własną podstawę, to $\mathrm{z}$ czego wyrasta. Wyrasta natomiast $\mathrm{z}$ wydarzenia Nowego Bytu, z Wcielenia. Jeśli istnieją ludzie, których egzystencja przemienia się przez wiarę w Chrystusa, to jednocześnie muszą oni być pewnymi faktyczności Chrystusa. Wiara zatem zapewnia, że zgodnie ze świadectwami Nowego Testamentu pojawił się człowiek, w którym w pełni zajaśniał blask bogoczłowieczeństwa. Tak więc o ile wiara nie mówi nic o historycznym Jezusie, a zatem o konkretnym konstrukcie wytworzonym w wyniku naukowych badań, o tyle mówi o faktycznym Jezusie - o tym, że ktoś taki faktycznie pojawił się na ziemi. Trzeba jednak — mówi Tillich — postawić kolejne pytania: Czy rzeczywiście nie da się nic powiedzieć o Jezusie? Czy Jego życie, kształt Jego egzystencji nie ma żadnego znaczenia? Ostatecznie pojęcie Nowego Bytu pozostaje puste, jeśli o Jezusie wiemy tylko tyle, że istniał. Przecież są powody, dla których to właśnie w tym człowieku uczniowie zobaczyli Chrystusa. Czy więc wiara naprowadza jednak na jakiś konkretny obraz Jezusa?

Wielu teologów, biblistów i historyków rozważa problem ciągłości między historycznym Jezusem a opowieścią biblijną o Chrystusie ${ }^{20}$. Zdaniem Tillicha pewne i istotne jest, że wiara daje konkretny obraz Chrystusa, w którym zostają przezwyciężone warunki wyobcowanej egzystencji ${ }^{21}$. Obraz ten jest swego rodzaju religijnym wyobrażeniem, a nie historycznym reportażem. Nie znaczy to jednak, że wyobrażenie to zupełnie nie przystaje do tego, co faktycznie zaszło w życiu historycznego Jezusa. Obraz Chrystusa, jakiemu świadectwo dają Ewangelie, jest powiązany z doświadczaną przez pierwszych uczniów egzystencją Jezusa. Jest on niejako nabudowany na tej egzystencji. Istnieje zatem ciągłość między Jezusem historii a Chrystusem wiary. Podobnie jak wyobrażenie Chrystusa zostało nałożone przez pierwszych

\footnotetext{
${ }^{19}$ Por. Tillich, Teologia systematyczna, t. 2, 110.

${ }^{20}$ Dla polskiej myśli teologicznej przełomowa w tym względzie była praca Józefa Kudasiewicza Jezus historii a Chrystus wiary (Lublin: Redakcja Wydawnictw KUL, 1987). Zob. także: Józef Kudasiewicz i Henryk Witczyk, Jezus i Ewangelie w ogniu dyskusji. Od H. Reimarusa do T. Polaka (Kielce: Instytut Teologii Biblijnej Verbum, 2011).

${ }^{21}$ Por. Tillich, Teologia systematyczna, t. 2, 110.
} 
chrześcijan na historię Jezusa, tak i współcześnie można odkrywać, że biblijny obraz Chrystusa współgra z historyczną egzystencją Jezusa. Tak więc można wnioskować na temat Jezusa poprzez analogię biblijnego obrazu. Tillich określa tę oryginalną koncepcję mianem analogia imaginis ${ }^{22}$. Poprzez kontakt z obrazem Chrystusa, jaki wyłania się z Ewangelii, osoba wierząca dociera przez analogię do postaci Jezusa historycznego. Nie gwarantuje to autentyczności historycznej konkretnych epizodów czy słów z Ewangelii - ta na zawsze pozostanie niepewną, ale też, według teologa, niezbyt istotną dla wiary. Dlatego na przykład Kenneth Hamilton zarzuca Tillichowi zbytnie oderwanie teologii od podstawy historycznej ${ }^{23}$. Tymczasem dla amerykańskiego myśliciela istotny jest biblijny wizerunek Jezusa Chrystusa, który odpowiada rzeczywistemu wydarzeniu. Tym wydarzeniem jest życie Jezusa z Nazaretu, które zostało przyjęte przez Jego uczniów jako życie, w którym - jak zauważa Anne M. Reijnen - w pełni objawia się Bóg, a więc w którym samo Boże Słowo dochodzi do głosu ${ }^{24}$. Mówiąc językiem Tillicha, w życiu Jezusa ukazał się Nowy Byt, nowe stworzenie. Odwieczna jedność Boga i człowieka stała się ciałem, konkretem egzystencji. Tym samym punktem zapalnym chrześcijaństwa rzeczywiście było faktyczne życie Jezusa. Choć nie ma co do jego szczegółów naukowej pewności, istnieje pewność wiary co do faktyczności zbawienia, które przyszło na świat za pośrednictwem Jezusa z Nazaretu. Dostęp do tego pośredniczącego życia jest wciąż możliwy poprzez analogia imaginis.

Życie Jezusa stoi zatem u podstaw dogmatycznej chrystologii, ale w sposób pośredni. Natomiast właściwym przedmiotem zarówno chrystologii, jak i samej wiary jest Jezus jako Chrystus. Taką właśnie formułą, brzmiącą dość niecodziennie, Tillich najczęściej opisuje postać Zbawiciela. Jezus jest przedmiotem wiary nie jako Jezus, lecz jako Chrystus ${ }^{25}$. Takie jest właśnie znaczenie zbitki wyrazowej „Jezus Chrystus”, która jednak w potocznym użyciu zdezawuowała się i zaczęła być traktowana niemal jako imię i nazwisko ${ }^{26}$. „Chrystus" nie jest ani nazwiskiem, ani nawet przydomkiem Jezusa. Jest to

\footnotetext{
${ }^{22}$ Por. Tillich, Teologia systematyczna, t. 2, 111.

${ }^{23}$ Por. Kenneth Hamilton, The System and the Gospel (Michigan: Macmillan, 1963), 170.

${ }^{24}$ Por. Anne Marie Reijnen, "Tillich's Christology", w: The Cambridge Companion to Paul Tillich, red. Russell Re Manning (Cambridge: Cambridge University Press, 2009), 68.

${ }^{25}$ Gdy Jezus staje się obiektem zainteresowania wiary jako jedynie postać historyczna, wówczas zachodzi — zdaniem Tillicha — niebezpieczeństwo idolatrii. To właśnie miało miejsce już w czasach samego Jezusa, gdy stawał się On idolem otaczających Go thumów, oczekujących od Niego zapoczątkowania narodowej rewolucji czy religijnego przewrotu. Por. Tillich, The New Being, 133.

${ }^{26}$ Por. Tillich, Teologia systematyczna, t. 2, 96.
} 
określenie wiary, która w Jezusie widzi pośrednika Nowego Bytu. Nazywając Jezusa Chrystusem, każdorazowo wyznaje się wiarę. Jeśli Jezus jest dla kogoś tylko Jezusem, czyli konkretną historyczną jednostką, nie można jeszcze mówić o wierze chrześcijańskiej. Wówczas Jezus może być bowiem najwyżej jedną z wybitnych postaci religijnych, stojącą obok Buddy czy Mahometa. Jeśli natomiast Jezusa doświadcza się jako źródło ponadhistorycznego zbawienia, jeśli partycypuje się w przyniesionym przez Niego Nowym Bycie, wówczas zaczyna się przygoda wiary. Chrześcijanie dlatego zwykli określać Jezusa mianem Chrystusa, myśląc o tym, że Jezus rzeczywiście jest Chrystusem, czyli Bożym Pomazańcem, przynoszącym nowy stan rzeczy.

To właśnie Jezus będący Chrystusem, czyli Jezus jako Chrystus, stanowi - według Tillicha - centrum chrystologii, a zarazem chrześcijaństwa. „Wydarzenie bowiem, na którym opiera się chrześcijaństwo, ma dwie strony: fakt o nazwie «Jezus z Nazaretu» oraz recepcję tego faktu przez tych, którzy przyjęli Go jako Chrystusa" ${ }^{27}$. On jest pośrednikiem, w którym Nieuwarunkowane zbawia przez uwarunkowane. Sam Chrystus bez Wcielenia pozostałby jakąś religijną ideą. Idea zaś nie może być źródłem zbawienia, dopóki nie ziści się w konkretnej, doświadczalnej egzystencji — zbawia bowiem osoba, a nie idea. Natomiast sam Jezus jako Jezus również nie może być źródłem zbawienia, bo żaden człowiek, nawet najświętszy, nie może być sam z siebie dawcą zbawienia. Teraz widać wyraźnie, w jakim sensie osobista historia Jezusa z Nazaretu ma znaczenie dla zbawczego pośrednictwa Jezusa Chrystusa. Otóż same wydarzenia tej historii, pozbawione odniesienia transcendentnego, nie są źródłem zbawienia. Jezus w żadnym swoim akcie nie jest Zbawicielem jako Jezus. Jest nim natomiast jako Chrystus, czyli jako namaszczony przez Boga, reprezentujący Go. To Wcielone Słowo zbawia człowieka i to Ono objawia się w życiu Jezusa. Każdy partykularny element życia Jezusa ma znaczenie zbawcze, ale nie dlatego, że jest to życie tak wyjątkowe czy spektakularne. Jest tak dlatego, że to właśnie przez to życie objawia się Logos, ujawniając odwieczną jedność Boga i człowieka i w ten sposób zbawiając wszystkich, którzy partycypują w Jego mocy przez wiarę ${ }^{28}$.

Patrząc na to, jak Tillich widzi relację między Jezusem historii a Chrystusem wiary, można powiedzieć, że jest to relacja pośrednictwa. Chrystus objawia się w konkretnym ludzkim życiu, Boże Słowo staje się ciałem. Lo-

\footnotetext{
${ }^{27}$ Tillich, Teologia systematyczna, t. 2, 95.

${ }^{28}$ Por. Paul Tillich, ,A Reinterpretation of the Doctrine of the Incarnation”, w: Main Works/ Hauptwerke, Bd. VI, red. Gert Hummel (Berlin / New York: De Gruyter, 1992), 315.
} 
gos więc staje się dostępny człowiekowi poprzez konkretne ludzkie życie. Tym życiem jest oczywiście życie Jezusa z Nazaretu. Każde wydarzenie tego życia, każdy spisany i zapamiętany przez pamięć wiary epizod zyskuje znaczenie zbawcze. Opowieści o Jezusie nie są ani pobożnymi legendami, ani rzetelną historiografią. Są świadectwem wiary, wyrosłym ze spotkania z Wcielonym Słowem. Poprzez Niego objawia się w pełni i zbawia nas sam Nieuwarunkowany Bóg. Oznacza to, że Jezus jest wcielonym Słowem Boga. Dlatego każdy element tego życia, każda jego postawa, każde wydarzenie staje się nośnikiem zbawczej mocy Nowego Bytu ${ }^{29}$. Spotykając Jezusa jako Chrystusa, spotyka się samego Boga. Jezus Chrystus jest pośrednikiem totalnym w tym znaczeniu, że Bóg nie tylko objawia się w Nim w całej pełni, ale także przez Niego w pełni zbawia świat. Historia Jezusa, Jego ziemskie losy, są w całej rozciągłości jedynym Słowem Boga.

Tym samym pośrednictwo historycznego Jezusa mówi o tym, że wszelkie pośrednictwo składa się niejako z dwóch elementów. Łączy w sobie to, co uwarunkowane, i to, co Nieuwarunkowane. Sam Jezus jako postać historyczna jest wszak wielorako uwarunkowany. Pojawił się na świecie w takich, a nie innych okolicznościach, był synem konkretnego narodu, miał konkretną rodzinę, osobowość, język, kulturę, a nawet wygląd zewnętrzny. Również wydarzenia z Jego życia mają charakter uwarunkowany. Są wynikiem wielorakich zależności, współgrają z wydarzeniami politycznymi i społecznymi, są także utkane z wielu decyzji ludzi spotykających się z Nim. Ostatecznie jest to historia w pewnym sensie przypadkowa, łącząca w sobie wolność, ale i przeznaczenie. Jest to po prostu historia prawdziwa, żadną miarą nie jest ona jakimś zaplanowanym $\mathrm{z}$ góry teatrem ${ }^{30}$. Także finał tej historii nie jest realizacją planu $\mathrm{w}$ znaczeniu jakiegoś boskiego dekretu. W tym znaczeniu cała historia Jezusa, aż po kres jest autentycznie ludzką historią, ludzkim losem. Los Jezusa zależy od Jego wyborów, ale też od wyborów innych ludzi, którzy przyjmują Go lub odrzucają. W tym sensie historia Mistrza jest zwyczajną historią ludzką, a nie zadekretowanym odgórnie spektaklem. Ale właśnie ta konkretna, uwarunkowana historia, podobna do każdej ludzkiej historii, jest pośrednikiem Bożego zbawienia. Takie jest pośrednictwo historycznego Jezusa, ale taka jest także prawda o samym pośrednictwie teologicznym jako takim. Polega ono na tym, że Nieuwarunkowane jawi się w uwarunkowanym i przez nie pociąga człowieka ku sobie.

\footnotetext{
${ }^{29}$ Por. Tillich, Teologia systematyczna, t. 2, 120.

${ }^{30}$ Por. Grzegorz Barth, Hermeneutyka osoby (Lublin: Wydawnictwo KUL, 2013), 278.
} 
Pośrednictwo Chrystusa w myśli Tillicha ukazane jest w sposób przejrzysty i inspirujący dla teologicznych poszukiwań. Spojrzenie teologa nie jest jednak pozbawione swoich słabych stron. Jak już wspomniano, wątpliwości może budzić tak radykalne odcięcie chrystologii dogmatycznej od obrazu Jezusa, jaki wyłania się z badań historycznych. Wydaje się, że uwzględnienie historycznego kontekstu życia Jezusa i krytycznohistoryczne spojrzenie na teksty Nowego Testamentu mają swoje znaczenie dla teologii. Tillich natomiast konstruuje swoją myśl niejako poza tym kontekstem, wpadając w pułapkę pewnej ahistoryczności. Teologia budowana w oderwaniu od wymiaru historycznego może momentami zbliżać się do oderwanego od konkretnej treści systemu pojęć. Tillich raczej nie popada w taką skrajność, jednak można odnieść wrażenie, że niekiedy się do niej niebezpiecznie zbliża. Jego Chrystus czasem jawi się jako pojęcie, idea, nawet jeśli zakorzeniona $\mathrm{w}$ autentycznym wydarzeniu.

\section{POŚREDNIK W ZWYCIĘSTWIE NAD GRZECHEM}

Chrystus jest pośrednikiem zbawienia, ponieważ w Jego życiu dokonuje się zwycięstwo nad grzechem, który związał się z egzystencją człowieka. Grzech to przede wszystkim osobowy akt odwrócenia się od Boga, co w myśli Tillicha odpowiada kategorii wyobcowania człowieka z gruntu jego bytu ${ }^{31}$. W życiu Jezusa Chrystusa dokonuje się zwycięstwo nad tą mroczną siłą, wyrywającą egzystencję z jej boskiego korzenia. W całym życiu Chrystusa jaśnieje Nowy Byt, w którym to właśnie zwycięstwo zostaje faktycznie zrealizowane. Nowy Byt przejawia się przez cały byt Jezusa Chrystusa. Wszystkie elementy życia Jezusa są wyrazem obecnego w Nim Nowego Bytu. Nie jest natomiast odwrotnie, a więc nie jest tak, że to jakieś konkretne elementy życia Jezusa czynią go Zbawicielem. Jak zaznacza Tillich, Chrystus dokonuje tego, czego dokonuje, bo jest Zbawicielem, nie zaś odwrotnie $^{32}$. Dlatego na poszczególne elementy składające się na biblijny wizerunek Jezusa Chrystusa trzeba patrzeć jako na owoce Nowego Bytu działającego w Nim. Nie można natomiast upatrywać przyczyny zbawienia w żadnym elemencie tego wizerunku. Pamiętając o tym, warto teraz prześledzić te wszystkie elementy, które są owocem Nowego Bytu obecnego w Jezusie, jego przejawem.

\footnotetext{
${ }^{31}$ Por. Tillich, Teologia systematyczna, t. 2, 49.

${ }^{32}$ Por. ibid., 157.
} 
Pierwszym z tych elementów są słowa Jezusa, jakie kierował on do swoich uczniów, szerszego grona słuchaczy, a także oponentów ${ }^{33}$. Chodzi zatem o wszystkie te słowa, które zostały spisane w Ewangeliach kanonicznych jako wypowiedzi Jezusa. Zdaniem Tillicha w słowach tych przejawia się moc Nowego Bytu. W tym sensie są one zbawcze i mają moc zbawić tego, kto ich słucha. Słowa Jezusa nie mają jednak mocy zbawczej same w sobie. Nie jest tak, że tożsamość Jezusa wynika z słów, które wypowiedział. Przeciwnie, to Jego tożsamość jako Słowa poprzedza jego konkretne słowa ${ }^{34}$. Dzieje się to nie tylko względem słuchaczy bezpośrednich, ale - jak pokazuje historia Kościoła - także względem tych, którzy nie spotykając Jezusa historycznego osobiście, stykają się z Jego słowami przekazanymi im. Słowa Jezusa mają wielką moc, ale przede wszystkim to sam Jezus jest Słowem ${ }^{35}$. To właśnie jedyne Słowo Ojca wypowiada te słowa, i to dlatego mają one moc przemieniać serca. Nie zaś dlatego, że są szczególnie mądre, przemyślane czy głębokie, choć oczywiście są takie. Pamiętając o tym wszystkim trzeba odrzucić taką teologię, która widzi w Jezusie przede wszystkim nauczyciela, głosiciela jakichś szczególnych nauk. Jeśli słowa Jezusa stają w centrum, wciąż pozostajemy na drodze samozbawienia. Przykładami takich ujęć są według Tillicha nurty racjonalistyczne w teologii, na czele $\mathrm{z}$ tak zwaną teologią liberalną ${ }^{36}$.

Drugim istotnym elementem egzystencji Jezusa, przez który działa zbawienna moc Nowego Bytu, są czyny. Przez wszystko to, czego Jezus dokonuje, przejawia się moc zbawiającego Boga. Czyny Jezusa nie dotyczą tylko tych, wobec których w sposób namacalny zostały wykonane. Również współczesny odbiorca Ewangelii może doświadczyć zbawiennej mocy słuchając o czynach Jezusa. Są to po prostu czyny zbawcze. Znowu jednak trzeba zaznaczyć, że czynów Jezusa nie wolno oddzielać od Jego bytu ${ }^{37}$. Opowieść o Jezusie nie jest legendą o jakimś bohaterze, którego wielkie czyny zmieniły losy świata. Same w sobie te czyny nie mają żadnej mocy. Są to czyny Wcielonego Słowa, są to owoce Nowego Bytu. Dlatego i tylko dlatego są one zbawienne.

\footnotetext{
${ }^{33}$ Por. Tillich, Teologia systematyczna, t. 2, 116.

34 „Therefore, the Church calls not His words but His Being the Word of God". Tillich, The New Being, 121.

${ }^{35}$ Por. Tillich, Teologia systematyczna, t. 2, 117.

${ }^{36}$ Por. ibid., 103, 117.

${ }^{37}$ Por. ibid., 117-118.
} 
Jest to niezmiernie ważne, gdyż — jak podkreśla Tillich — bardzo popularna postawa imitatio Christi jest w tym właśnie punkcie dwuznaczna $^{38}$. Może ona wytworzyć przekonanie, że Jezus to ktoś, kogo należy po prostu podziwiać za wspaniałe dokonania, takie jak czynienie dobra dla innych, uzdrawianie, pochylanie się nad słabszymi i tym podobne. W centrum wiary staje wówczas historia Jezusa ziemskiego jako historia wspaniałych czynów, które warto naśladować. „«Imitatio Christi» pojmuje się często jako próbę przekształcenia swojego życia w kopię życia Jezusa, łącznie z konkretnymi rysami wizerunku biblijnego"39. Znowu otwiera się wówczas pokusa samozbawienia. Tym razem prawem nie są słowa Jezusa, lecz same Jego czyny. Obowiązkiem chrześcijanina ma być naśladowanie Chrystusa w najdrobniejszych szczegółach, naśladowanie Jego życia. Jest to ostatecznie nie tylko błędne teologicznie, ale i samo w sobie absurdalne. Każdy człowiek ma swój konkretny kontekst życia i nie można przenieść w inną epokę literalnie tych samych czynów, których dokonywał Jezus dwa tysiące lat temu. Naśladowanie Chrystusa jest oczywiście słuszne, ale nie można tego rozumieć jako czynienia ze swojego życia kopii życia Jezusa ${ }^{40}$. Jest to po prostu niemożliwe, a poza tym nie jest to rzeczywista droga zbawienia $^{41}$.

Trzecim istotnym elementem, który Tillich wyróżnia obok słów i czynów, jest cierpienie Jezusa ${ }^{42}$. Wiadomo, że mówiąc o nim, myśli się zasadniczo o męce i krzyżowej śmierci Chrystusa. Sprawę zbawczego charakteru tejże śmierci trzeba omówić dokładniej, w odrębnym paragrafie. Tutaj natomiast wystarczy pokrótce omówić, w jaki sposób cierpienie Jezusa ma charakter zbawczy. Niewiele można dodać po tym, co zostało powiedziane o słowach i czynach. Cierpienia Chrystusa, które przez wieki koncentrowały na sobie

\footnotetext{
${ }^{38}$ Warto zwrócić na to uwagę choćby dlatego, że znana książka ascetyczna $O$ naśladowaniu Chrystusa jest jedną z najpopularniejszych, najczęściej drukowanych i czytanych książek chrześcijańskich w ogóle. Biorąc pod uwagę całość tego dzieła, trzeba powiedzieć, że gdy autor na początku mówi: „Starajmy się więc rozpamiętywać jak najgorliwiej życie Jezusa Chrystusa”, nie ma na myśli wejścia na drogę literalnego naśladownictwa szczegółów życia Pana, lecz wejście na Jego duchową drogę. Tomasz à Kempis, $O$ naśladowaniu Chrystusa, tłum. Anna Kamieńska (Warszawa: PAX, 1980), 21.

${ }^{39}$ Tillich, Teologia systematyczna, t. 2, 117.

${ }^{40}$ Ciekawą, egzystencjalno-moralną perspektywę naśladowania Chrystusa pokazuje Tadeusz Zadykowicz w książce Sequela Christi et imitatio hominis. Paradygmat naśladowania we wspótczesnej refleksji teologicznomoralnej. Źródta i perspektywy (Lublin: Wydawnictwo KUL, 2011).

${ }^{41}$ Poza tym często postawę naśladowania Chrystusa rozumie się jako dążenie do dyscypliny moralnej i skrajnej ascezy, zapominając, że Jezusa nazywano ,żarłokiem i pijakiem” (por. Mt 11, 19; Łk 7,34). Por. Tillich, The New Being, 148.

${ }^{42}$ Por. Tillich, Teologia systematyczna, t. 2, 118.
} 
uwagę wielu pokoleń chrześcijan, nie mogą być widziane jako coś odrębnego, co samo w sobie ma zbawczą wartość. Właściwie w przypadku cierpienia chyba najłatwiej zrozumieć, że istotne jest to, kto cierpi, a nie same męki. Wiele osób przeżyło straszne cierpienia fizyczne, być może silniejsze niż te, których Chrystus doświadczył na krzyżu. Tysiące osób było zresztą krzyżowanych dokładnie w taki sam sposób jak Jezus, a jednak to tylko o Nim jednym mówi się, że Jego cierpienie ma wartość zbawczą. Chodzi oczywiście o to, że nie można Chrystusowego cierpienia oddzielać od Jego bytu.

Męka Chrystusa daje zbawienie, bo jest męką Wcielonego Słowa, które wchodząc $\mathrm{w}$ egzystencję trwa $\mathrm{w}$ niej aż do końca, przyjmuje na siebie śmierć $^{43}$. Bóg zbawił ludzi za pośrednictwem cierpienia Chrystusa. Prawda ta nie może jednak rodzić koncentracji na samym tym cierpieniu, co czynią niektóre typy pasyjnej pobożności. Wielokrotnie pobożność ta zapomina, że chodzi o cierpienie Syna Bożego, nie zaś o to, że samo cierpienie jest w jakiś sposób godne czci. Zagrożenie płynące $\mathrm{z}$ koncentracji na cierpieniu Chrystusa jest chyba jeszcze większe niż to związane z przywiązywaniem całej uwagi do słów lub czynów Zbawiciela. Tutaj groźbą jest bowiem przypisanie zbawczej wartości cierpieniu jako takiemu, co może rodzić potrzebę dobrowolnego poszukiwania cierpienia albo niechęci do wspierania cierpiących i pomagania im w wychodzeniu z niego. Dlatego tym bardziej trzeba stwierdzić z całą mocą, że cierpienie Chrystusa jest zbawienne dlatego, że jest cierpieniem Chrystusa. Logos, przyjmując egzystencję, utożsamia się $\mathrm{z}$ nią aż do dramatycznego jej kresu.

Te trzy elementy, jakimi są słowa, czyny i cierpienia Chrystusa, pokazują, że sama Jego osoba jest Pośrednikiem i źródłem wszelkiego pośrednictwa. Tutaj chodzi szczególnie o pośrednictwo w zbawieniu, czyli w zwycięstwie nad tragicznym rozbiciem egzystencji. Jak dokonuje się to zwycięstwo? Oczywiście za pośrednictwem ludzkiej historii Jezusa, która jest historią zwycięstwa nad pokusą ${ }^{44}$. Nie chodzi jedynie o słynną synoptyczną perykopę dotyczącą trzech pokus Jezusa. Idzie o całe Jego życie, które świadczy o radykalnym oparciu się złu i zwycięstwie nad nim. Zdaniem

${ }^{43}$ „Tylko Mesjasz może wzbudzić życie ze śmierci. Nie jest to wydarzenie naturalne. Nie wydarza się każdego dnia, ale wydarza się w dniu Mesjasza. Jest to najbardziej zadziwiające, najgłębsze i najparadoksalniejsze misterium bycia. Życia z grobu nie da się wyprowadzić poprzez powoływanie się na nieśmiertelność jakiejś rzekomo lepszej części naszego osobistego ja. Wieczne życie powstaje tylko przez Przyjście «Nowej Rzeczywistości», która według naszej wiary już ukazała się w Jezusie jako Chrystusie". Paul Tillich, Prawda jest w głębi, tłum. Jan Adrian Łata (Wrocław / Oleśnica: Signum, 1996), 145.

${ }^{44}$ Por. Tillich, Teologia systematyczna, t. 2, 124. 
Tillicha egzystencja będąca $\mathrm{w}$ stanie grzechu wiąże się nieuchronnie $\mathrm{z}$ trzema etapami. Pierwszym jest niewiara, która oznacza wyobcowanie człowieka $\mathrm{z}$ gruntu jego bytu ${ }^{45}$. Niewiara to nie brak jakiegoś religijnego przekonania, lecz odcięcie się od Boga jako źródła bytu człowieka ${ }^{46}$. „Niewiara w opinii założycieli Reformacji nie jest niechęcią czy niezdolnością do uwierzenia w doktryny Kościoła, lecz — tak jak wiara — jest aktem całej osobowości, łącznie z elementami praktycznymi, teoretycznymi i emocjonalnymi" ${ }^{47}$. Kolejnym elementem zanurzonej w grzechu egzystencji jest hybris, co w pewnym uproszczeniu można tłumaczyć jako pycha. Jest to nieunikniony skutek niewiary. Skoro bowiem człowiek detronizuje Boga, natychmiast sam zasiada na tronie swojego życia. Tym właśnie jest hybris, a więc uznaniem siebie samego za ostateczny punkt odniesienia ${ }^{48}$. Kolejnym wreszcie etapem jest pożądliwość, która oznacza chęć zagarnięcia wszystkiego dla siebie. Ponieważ człowiek odrzuca Boga i siebie samego czyni bogiem, zaczyna podporządkowywać całą rzeczywistość swojej jaźni. Realizuje się to nie tylko na płaszczyźnie seksualnej, ale też w dziedzinie wiedzy czy władzy. Wszystko właściwie zostaje przez człowieka zagarnięte ${ }^{49}$.

Wszystko to, dotycząc każdej wyobcowanej egzystencji, nie dotyczy wszakże Jezusa. W Jego życiu, podkreśla Tillich, nie widać ani śladu niewiary, pychy czy pożądliwości. Nie ma tam wyobcowania wobec Boga, przeciwnie - widać trwałą jedność z Nieuwarunkowanym, mimo wszelkich kryzysowych sytuacji. Nie ma tam żadnej pychy ani też pożądliwości. W obrazie Jezusa jako Chrystusa widać człowieka, który jest pojednany z Bogiem, ludźmi i samym sobą. Nic nie rozrywa tej jedności, jest ona trwała i bezwzględna. Dlatego można powiedzieć, że Jezus opiera się wszelkiej pokusie. Następuje w Nim zwycięstwo nad wyobcowaniem egzystencjalnym. Klasycznym terminem oznaczającym ten aspekt prawdy o Chrystusie jest bezgrzeszność. Jezus Chrystus jest bezgrzeszny, czyli rzeczywiście nie popełnił żadnego grzechu. Zdaniem Tillicha pojęcie to jest słuszne, choć niezbyt teologicznie udane ${ }^{50}$. Wskazuje ono bowiem na aspekt negatywny Chrystusowego zwycięstwa - brak grzechu. Tymczasem istotniejsze jest, by pokazać aspekt pozytywny, a więc jedność z Bogiem, ludźmi i samym sobą.

45 Jej psychologicznym korelatem jest, jak można domniemywać, lęk, czyli bezprzedmiotowy strach przed niebytem. Por. Tillich, Męstwo bycia, 64 .

${ }^{46}$ Por. Tillich, Teologia systematyczna, t. 2, 50-52.

${ }^{47}$ Tillich, Teologia systematyczna, t. 2, 50.

${ }^{48}$ Por. ibid., 52-54.

${ }^{49}$ Por. ibid., 54-57.

${ }^{50}$ Por. ibid., 121. 
Skutkiem tej jedności jest brak grzechu, jest on jednak sam w sobie czymś wtórnym ${ }^{51}$.

Brak grzechu u Jezusa nie oznacza, że jest On pozbawiony tragicznego elementu w swoim życiu. Ten punkt jest dość oryginalny i odważny w teologii Tillicha, dlatego warto mu się pokrótce przyjrzeć. Jezus Chrystus mianowicie, zdaniem teologa, zwycięża nad wyobcowaną egzystencją niejako od środka. Nie dotyka go grzech, w tym sensie, że nie poddaje się On pokusie. Dotykają Go jednak skutki grzechu, które wprowadzają Go w sytuację tragiczną. Sytuacja egzystencjalna człowieka jest tragiczna, a więc wcielony Logos wszedł w taką właśnie, tragiczną sytuację. Jezus podpada pod taką sytuację, w której swoją niewinnością sprawia winę innych ludzi ${ }^{52}$. Chodzi oczywiście o Jego oponentów i wreszcie oprawców. Tillich zachęca do tego, by dostrzec tragiczny element w sporze Jezusa z Żydami. „Jezus był uwikłany w tragiczny element winy, o ile czynił swych wrogów w sposób nieuchronny winowajcami" 53 . Żydzi stoją ostatecznie na straży Bożego prawa i starają się je wypełniać w sposób konsekwentny. Jezus w pewien sposób burzy ich porządek, prowokując ich do wrogiej reakcji. Następuje tu pewien paradoks, oto bowiem Żydzi, stojąc na straży objawienia przygotowawczego, jakim jest przecież Prawo, nie są w stanie przyjąć objawienia finalnego, a więc Chrystusa. Są oni wierni Bogu, ale jednak stanowczo mu się sprzeciwiają. Nie mieliby takiej winy, gdyby nie działanie Chrystusa. $\mathrm{W}$ tym sensie jest On tragiczną przyczyną ich grzechu ${ }^{54}$.

Podobnie ma się rzecz z bezpośrednimi sprawcami Jezusowej śmierci, zwłaszcza z Judaszem. Został on wszak wybrany na jednego z dwunastu Apostołów przez samego Jezusa. Można powiedzieć, że gdyby Chrystus go nie spotkał i nie wybrał, Judasz nie popełniłby swojej straszliwej zdrady.

\footnotetext{
${ }^{51}$ Współczesną dyskusję teologiczną na temat bezgrzeszności Jezusa referuje Grzegorz Strzelczyk - zob. jego „Bezgrzeszność Jezusa jako problem współczesnej chrystologii systematycznej”, Śląskie Studia Historyczno-Teologiczne 42, nr 2 (2009): 49-58.

${ }_{52}$ Por. Tillich, Teologia systematyczna, t. 2, 126.

${ }^{53}$ Ibid., 126.

${ }^{54}$ Warto wspomnieć, że podobnie niejednoznaczną sytuację Jezusa, a tym samym swoistą interpretację Jego bezgrzeszności, przedstawiał także inny wielki teolog protestancki, Dietrich Bonhoeffer. Pisał on o Jezusie: „Nie był dobrem już doskonałym. W każdej chwili znajdował się w stanie walki. To, co czynił, wyglądało — od zewnątrz przynajmniej — jak grzech. Bywał gniewny, był twardy wobec własnej matki, wykręcał się przeciwnikom, łamał prawa narodu, do którego należał, nawoływał do oporu przeciw panującym i pobożnym swego kraju. W oczach ludzi musiał być grzesznikiem. Wszedł w grzeszny sposób życia człowieka tak głęboko, że był w nim nie do poznania". Dietrich Bonhoeffer, Wybór pism, tłum. Anna Morawska (Warszawa: Więź, 1970), 39-40.
} 
Trzeba przy tym wyraźnie stwierdzić, że nie oznacza to żadnej moralnej winy Jezusa - takie postawienie sprawy byłoby absurdem. Chodzi po prostu o to, że życie każdego człowieka jest tragiczne, ma aspekt tragedii, a życie Jezusa nie stanowi w tym wyjątku. Chrystus zwycięża nad egzystencją nie w ten sposób, że Jego życie jest spokojne i proste, lecz dlatego, że Jego serce jest takie. To nieprzejednana postawa Chrystusa, wynikająca z Jego jedności z Ojcem, jest źródłem zbawienia. Wydaje się, że to właśnie chce podkreślić Tillich, zwracając uwagę na uczestnictwo Jezusa w tragicznym aspekcie losu ludzkiego.

Tym jednak, co jest przejawem Nowego Bytu i źródłem zbawienia ludzi, jest nie tyle samo uczestnictwo Jezusa w ludzkim predykamencie, lecz Jego niezłomna jedność z Bogiem. Chodzi przede wszystkim o to, że Jezus Chrystus, mimo wszelkich przeciwności, trudów, zmagań i wątpliwości, które dotykały Go tak jak każdego człowieka, nie zerwał w żaden sposób swojej jedności z Ojcem. Nie ma w Nim żadnego wyobcowania, wyrwania z gruntu bytu. We wszystkim, co się z Nim dzieje, Jezus zachowuje doskonałą jedność z Bogiem. To właśnie dlatego staje się On zwycięzcą nad egzystencjalnym wyobcowaniem. Tillich zaznacza przy tym, że nie chodzi tu o żadnego rodzaju fanatyzm ${ }^{55}$. W ewangelicznym obrazie Chrystusa nie widać żadnego fanatyka, który ślepo odnosi wszystkie fakty swojego życia do transcendencji, na sposób bezmyślny i automatyczny. Nie jest to obraz kogoś, kto zachowuje niewzruszoną pewność takiego rodzaju, że likwidowałaby ona powagę wątpliwości, cierpienia i zagubienia ${ }^{56}$. Jezus z całą powagą wchodzi w sytuacje niezrozumienia, wątpliwości i wreszcie krzyża. Jezus naprawdę doświadcza opuszczenia, samotności, cierpienia i wchodzi w trudne sytuacje świadomie, bez fanatycznego dystansu. Trwała jedność Jezusa z Bogiem nie polega na braku trudnych sytuacji czy lekceważeniu ich w duchu fanatyzmu. Jest to jedność pomimo wszelkich przeciwności i dramatów. Jest to bardzo istotne, by zauważyć, jak pisze Tillich, że Zbawiciel nie jest jakimś „,boskoludzkim automatem"57. Chrystus nie jest aktorem odgrywającym rolę człowieka, lecz naprawdę jest człowiekiem, posiadającym w swojej historii trudne chwile, wstrząsy, wątpliwości i osobiste dramaty.

\footnotetext{
${ }^{55}$ Por. Tillich, Teologia systematyczna, t. 2, 128.

${ }^{56}$ „Jezus nie rości sobie prawa do absolutnej pewności w obszarze jakiegoś skończonego przeświadczenia. Odrzuca On fanatyczną postawę uczniów wobec tych, co za Nim nie podążają. W mocy takiej pewności, która przekracza zarówno pewność i niepewność tak w sprawach religii, jak i życia świeckiego, uznaje niepewność za element skończoności”. Tillich, Teologia systematyczna, t. 2, 128.

${ }^{57}$ Ibid., 128.
} 
Nowy Byt w Jezusie jawi się w ten sposób, że mimo tych wszystkich trudności Jezus zachowuje doskonałą jedność z Bogiem. Jest to więc wizerunek jak najbardziej realnego życia osobowego, które doświadcza wszystkich tych trudności, jakich doświadcza każdy człowiek, a jednocześnie trwa w pierwotnej jedności z Bogiem. Jest to obraz życia, które opiera się złu, zwycięża nad pokusą egoizmu. Jezus przyjmuje cały tragiczny aspekt życia ludzkiego i włącza go niejako w jedność z Bogiem. Dramat egzystencji zostaje pokonany nie w ten sposób, że zostaje pominięty lub zlekceważony, ale w taki sposób, że zostaje umieszczony w bosko-ludzkim zjednoczeniu. Właśnie dlatego obraz Jezusa jako Chrystusa jest tak wiarygodny, a jednocześnie paradoksalny. To dlatego także historia Jezusa jest dla człowieka Dobrą Nowiną, pokazującą, że mimo wszystko życie w jedności z Bogiem jest możliwe i naprawdę się dzieje. Można więc powiedzieć ponownie, że Chrystus pośredniczy we wkroczeniu na arenę świata bogoczłowieczej jedności ${ }^{58}$.

Pozostaje pytanie, jak właściwie dokonuje się to zbawienie. Co właściwie ma dać człowiekowi to, że dwa tysiące lat temu żył człowiek w pełni zjednoczony z Bogiem? Myśl Tillicha nie daje jasnej odpowiedzi na to pytanie, co jest jej niewątpliwym mankamentem. Chrystus jawi się jako ten, kto pokonał egzystencjalne wyobcowanie - co jednak daje innym ludziom to, że On je pokonał? Jeśli potraktować Chrystusa po prostu jako przykład i wzór, wpadamy w pułapkę pelagianizmu. Jeśli natomiast pójść w kierunku myślenia o Duchu Świętym jako tym, który dokonuje w nas zbawienia, to pozostaje pytanie, czy do daru Ducha konieczna była historia Jezusa. Ktoś mógłby zapytać, czy Bóg nie mógłby udzielić ludziom Ducha Świętego bez Wcielenia Słowa w Jezusie. Teologia Tillicha ewidentnie chce uniknąć rozwiązań soteriologicznych w rodzaju anzelmiańskiej teorii satisfactio, można jednak odnieść wrażenie, że w pewnych punktach nie daje wiele w zamian.

Pewne jest jednak, że według autora zbawienie, które przemienia egzystencję w kierunku bogoczłowieczeństwa, nie może być uzyskane przez człowieka własnymi siłami. Tillich punktuje obficie drogi samozbawienia i pokazuje ich nieuchronną porażkę. Są to drogi legalistyczne, usiłujące uzyskać zbawienie przez wypełnianie zasad prawnych ${ }^{59}$, dalej ascetyczne, które obiecują zbawienie poprzez poskramianie ludzkiej zmysłowości ${ }^{60}$. Następną drogą samozbawienia jest droga mistyczna, która chce samodzielnie osiąg-

\footnotetext{
${ }^{58}$ Por. Tillich, ,A Reinterpretation of the Doctrine”, 313.

${ }^{59}$ Por. Tillich, Teologia systematyczna, t. 2, 80-81.

${ }^{60}$ Por. ibid., 81-82.
} 
nąć jedność z Bogiem na drodze odpowiednich ćwiczeń duchowych ${ }^{61}$. Ponadto Tillich wymienia drogę sakramentalną, doktrynalną i emocjonalną. Co ciekawe, zdaniem Tillicha „droga sakramentalna jest bardziej charakterystyczna dla Kościoła rzymskokatolickiego, a doktrynalna dla Kościoła protestanckiego, zwłaszcza Kościołów luterańskich”62. Wszystkie te drogi są fałszywe, choć trzeba pamiętać, że w autentycznej wierze jest oczywiście miejsce na prawo, ascezę, mistykę, doktrynę i inne elementy. Są one jednak wtórne wobec zbawienia, którego może dokonać tylko sam Bóg. Tylko Nieuwarunkowane może uleczyć zniszczoną egzystencję i czyni to, wkraczając w świat przez Wcielenie.

\section{POŚREDNICTWO ZBAWCZE W WYDARZENIACH PASCHALNYCH}

Omawiając dzieło zbawcze dokonane w śmierci krzyżowej i zmartwychwstaniu Chrystusa w świetle teologii Paula Tillicha, trzeba pamiętać o pewnym nietypowym wydźwięku tej teologii. Tillich mianowicie nie poświęca zbyt wiele uwagi samej śmierci i zmartwychwstaniu, stając się w ten sposób teologiem bardzo swoistym. W teologii chrześcijańskiej, zwłaszcza zachodniej, od wieków koncentrowano się na wydarzeniach paschalnych, niekiedy wręcz zapoznając przy tym wcześniejsze, przedpaschalne życie Jezusa. Klasyczne teorie soteriologiczne ogniskują się wokół wydarzeń z Golgoty i grobu Pańskiego, upatrując w ostatnich chwilach życia Jezusa źródła tego, co nazywamy zbawieniem ${ }^{63}$. Tillich ustawia rzecz zupełnie inaczej. $\mathrm{W}$ jego przekonaniu dzieło zbawcze Chrystusa wyraźnie powiązane jest $\mathrm{z}$ całym życiem Mesjasza. Nie da się wyróżnić tylko śmierci i zmartwychwstania, lekceważąc przy tym to, co działo się z Jezusem wcześniej. Nowy Byt objawia się przecież w samym bycie Jezusa, nie zaś w jakimś jego konkretnym elemencie. Żadnego aspektu życia Chrystusa nie wolno absolutyzować, a — zdaje się twierdzić Tillich — dotyczy to również Paschy.

\footnotetext{
${ }^{61}$ Por. Tillich, Teologia systematyczna, t. 2, 82-83.

${ }^{62}$ Ibid., 83.

${ }^{63} \mathrm{Z}$ drugiej strony trzeba pamiętać, że już według Ojców Kościoła „Chrystus wysłużył ludziom odkupienie nie tylko swoją śmiercią na krzyżu, ale także całym wcielonym życiem. Nie pomniejszali oni kulminacyjnego punktu odkupienia, jakim było ukrzyżowanie i zmartwychwstanie, ale raczej umieszczali te wydarzenia w całym kontekście Chrystusowego działania zbawczego". Gerald O’Collins, Jezus nasz Odkupiciel. Chrześcijańskie ujęcie zbawienia, tłum. Jan Pociej (Kraków: Wydawnictwo UJ, 2009), 74.
} 
Zdarzenia z życia Jezusa mają uniwersalne znaczenie, stając się symbolami egzystencji pojednanej, zwycięskiej nad grzechem i złem. W tym względzie tajemnica Paschy jest po prostu szczytowym symbolem czy zespołem symboli oznaczających Chrystusowe zbawienie.

Tillich pokazuje wzajemną zależność krzyża i zmartwychwstania. Są to dla niego dwa symbole, których pod żadnym pozorem nie wolno rozrywać. Mówiąc o symbolicznym znaczeniu tych paschalnych wydarzeń, autor nie ma przy tym na myśli tego, że historyczny Jezus nie został ukrzyżowany. Chodzi jedynie o to, że samo w sobie ukrzyżowanie skazańca było zjawiskiem powszechnym i to nie ono jest jako takie znaczące. Sens ukrzyżowania Chrystusa jest symboliczny, wydarzenie to staje się symbolem i przez to jest nośnikiem zbawczego sensu. Najpierw trzeba więc przyjrzeć się symbolowi krzyża, aby później przejść do symbolu zmartwychwstania. Jak Tillich rozumie Chrystusowy krzyż? Aspekt historyczny jest tu podstawą, nie on jednak jest rozstrzygający. Co do samych historycznych szczegółów nie ma przecież żadnej pewności. Można zakładać jedynie tyle, że Jezus poddał się na koniec życia ostatecznej konsekwencji wyobcowania egzystencjalnego, jaką jest śmierć. A jednak „opowieść o Krzyżu Jezusa jako Chrystusa — pisze Tillich — nie relacjonuje jakiegoś wyodrębnionego wydarzenia w Jego życiu, ale to wydarzenie, na które nakierowana jest historia Jego życia i w świetle którego inne wydarzenia nabierają sensu" ${ }^{\prime 4}$.

Jaki jest sens symbolu krzyża, który streszcza całożyciową postawę Jezusa? Jest to symbol oznaczający poddanie się warunkom egzystencji. Na krzyżu faktycznie znajduje ono swój finał, gdy Jezus poddaje się śmierci jako ostatecznemu finałowi wyobcowanej egzystencji. W całym jednak swoim życiu Jezus pokornie poddaje się warunkom egzystencji, na tym wszak polega Wcielenie. Dlatego całe życie Chrystusa może być symbolizowane przez krzyż. Szczególnie niektóre fakty z życia Jezusa wskazują na ten „krzyżowy” charakter tego życia. Są to choćby liche warunki materialne towarzyszącego Jego narodzeniu, inne trudności egzystencjalne, męka w ogrodzie Getsemani ${ }^{65}$. Krzyż więc oznacza paradoks objawienia się Bożego Logosu w warunkach egzystencji. Boży Syn poddaje się warunkom życia zranionego grzechem, choć sam nie jest winien tego grzechu. Całe to poddanie kulminuje $\mathrm{w}$ momencie śmierci na krzyżu, który stał się $\mathrm{w}$ ten sposób symbolem Chrystusowego uniżenia. Dopowiadając: pośrednictwo w śmierci krzyżowej polegałoby więc na tym, że niewinny Syn Boży wchodzi

\footnotetext{
${ }^{64}$ Tillich, Teologia systematyczna, t. 2, 148.

${ }^{65}$ Por. ibid., 149.
} 
w warunki wyobcowanej egzystencji, ponosząc na sobie skutki grzechu ludzi. $\mathrm{W}$ ten sposób daje moc podległym warunkom egzystencji ludziom, aby przez udział w Jego zwycięstwie wytrwali w jedności z Bogiem.

Skorelowany z krzyżem symbol zmartwychwstania różni się od niego nieco pod kątem historycznej podstawy. O ile historyczność ukrzyżowania Jezusa jest niekwestionowana, o tyle historyczność zmartwychwstania jest co najmniej problematyczna. Teologowie pytają, czy można tu w ogóle mówić o fakcie historycznym, czy raczej o interpretacji historii lub o jakimś wydarzeniu przekraczającym historyczne ramy. Nie sposób wskazać historycznych dowodów na zmartwychwstanie, nie zmienia to jednak faktu, że uzasadnionym jest mówienie o nim jako o wydarzeniu. Można darować sobie przymiotnik „,historyczny”, który byłby tu problematyczny. Nie ulega jednak wątpliwości, że autorzy nowotestamentalni świadczą o wydarzeniu zmartwychwstania Chrystusa. Jednocześnie nie idzie tu o jakiś konkretny moment, który byłby obserwowany przez świadków, a następnie opisany. Nic takiego nie ma miejsca na kartach Biblii, natomiast są pewne historyczne przesłanki, które pozwoliły Apostołom uwierzyć w zmartwychwstanie $^{66}$. Chodzi oczywiście o odkrycie pustego grobu i o chrystofanie.

Gdy chodzi natomiast o samo rozumienie zmartwychwstania jako wydarzenia, Tillich omawia kilka funkcjonujących w teologicznym obiegu koncepcji. Pierwszą określa mianem teorii fizycznej. Odpowiada ona temu, co we współczesnej teologii fundamentalnej nazywa się niekiedy teorią reanimacji somatycznej ${ }^{67}$. W tym ujęciu zmartwychwstanie jest rozumiane jak najbardziej literalnie, a więc jako wyjście ożywionego na nowo historycznego Jezusa z grobu. Nawet na poziomie egzegezy takie wyjaśnienie musi zostać odrzucone, bo wydaje się ono dosyć wtórne i późne. Teza o pustym grobie, która jest — według Tillicha — znakiem takiej właśnie koncepcji, nie pojawia się w najstarszym, Pawłowym świadectwie paschalnym (1 Kor 15). Tillich utrzymuje, że fizykalna teoria jest późniejszą racjonalizacją dokonaną wobec pierwotnych świadectw o zmartwychwstaniu. „Wyłania się wtedy niedorzeczne pytanie - zauważa teolog - o to, co przytrafiło się molekułom, które składają się na zwłoki Jezusa z Nazaretu"68.

Druga teoria to teoria spirytualistyczna. W niej z kolei akcent pada na chrystofanie, które są rozumiane jako forma ukazywania się zmarłego,

\footnotetext{
${ }^{66}$ Por. Tillich, Teologia systematyczna, t. 2, 146.

${ }^{67}$ Por. Marian Rusecki, Pan zmartwychwstat $i$ żyje. Zarys teologii rezurekcyjnej (Warszawa: PAX, 2006), 103-106.

${ }^{68}$ Tillich, Teologia systematyczna, t. 2, 146.
} 
podobna do okultystycznych opowieści o pojawiających się duchach. A zatem ukazywanie się Chrystusa byłoby jakąś formą wizyty duszy z zaświatów, w której zmarły zapewnia, że po śmierci istnieje drugie życie. Oczywiście teolog odrzuca i tę teorię, wskazując choćby na to, że od takiego spirytualizmu odżegnują się już autorzy nowotestamentalni, zwłaszcza Łukasz, który w tym właśnie celu wprowadza w narrację posiłki Zmartwychwstałego, a nawet wkłada mu wprost $\mathrm{w}$ usta słowa odżegnujące się od spirytualizmu (Łk 24,39).

Trzecia interpretacja, według omawianego autora również błędna, to psychologizm $^{69}$. To raczej nowoczesna koncepcja, która pojawiła się dość późno, wraz z rozwojem nauk psychologicznych. Można by ją streścić następująco: zmartwychwstanie dokonało się w umysłach i przeżyciach tych, którzy wierzyli w Chrystusa. Tego typu koncepcje stają się dziś bardzo popularne, sugerując nawet, że wizje Zmartwychwstałego mogły być po prostu efektem tęsknoty przywiązanych do Jezusa uczniów za swoim Mistrzem $^{70}$. Tillich twierdzi jednak, że nie można by wtenczas mówić o realności zmartwychwstania.

Sam teolog proponuje więc jeszcze inną koncepcję. Według niego zmartwychwstanie oznacza, że obecność Chrystusa rozlewa się teraz na jego wierzących. Sam Chrystus jest realnie obecny i objawia się swoim uczniom, ale już nie jako historyczny Jezus, lecz jako Duch. Można by więc nazwać tę interesującą koncepcję mianem substytucji. Nowy Byt nie jest już obecny jako historyczna jednostka, ale jako Duch dający życie wielu. „W ten sposób konkretne indywidualne życie człowieka Jezusa z Nazaretu jest wydźwignięte ponad przemijalność do poziomu wiecznej obecności Boga jako Ducha"71. Chrystus — warto to zauważyć — pośredniczy tu swoim zmartwychwstaniem w wylaniu się Ducha Świętego.

Koncepcja Tillicha omija zatem alternatywę pomiędzy literalistycznym rozumieniem zmartwychwstania jako fizycznego powstania $\mathrm{z}$ grobu a subiektywistycznymi teoriami uznającymi zmartwychwstanie za jedynie osobiste doświadczenie uczniów. Propozycja substytucji ma jednak swoje wady, mianowicie jest problematyczna $\mathrm{z}$ dogmatycznego punktu widzenia. Jeśli Duch staje się nową formą obecności Jezusa, można zapytać, jak ma się to do tradycyjnych twierdzeń trynitologii. Wydaje się, że Tillich zbliża się tu do modalizmu, pokazując, że Bóg przestał działać jako Syn, a teraz pojawia

\footnotetext{
${ }^{69}$ Por. Tillich, Teologia systematyczna, t. 2, 146-147.

${ }^{70}$ Por. Rusecki, Pan zmartwychwstat i żyje, 95-96.

${ }^{71}$ Tillich, Teologia systematyczna, t. 2, 147.
} 
się już wyłącznie na sposób Ducha. Teoria, wedle której Syna zastępuje teraz Duch, wymagałaby pewnych uściśleń, bez których może sprawiać wrażenie, że osoby Trójcy Świętej zamieniają się rolami w kolejnych epokach, niczym w myśli Joachima de Fiore. Można odnieść wrażenie, że Tillich po raz kolejny chce uniknąć pewnych teologicznych trudności, podając alternatywne rozwiązanie problemu, samo jednak podane przez niego rozwiązanie także rodzi szereg problemów.

Trzeba jeszcze dodać, że analogicznie do symbolu krzyża także symbol zmartwychwstania streszcza i wypełnia wiele wydarzeń z życia Jezusa, a właściwie w pewien sposób całego Jego życie. Trzeba by tu wyróżnić wszystko to, co w historii Jezusa jest zwycięstwem nad wyobcowaniem, nad grzechem. Taki jest bowiem sens symbolu zmartwychwstania. Tillich wymienia więc cuda Jezusa, uzdrowienia, przemienienie na górze i inne ${ }^{72}$. Wszystko to streszcza się w zmartwychwstaniu, które ma następujące przesłanie: wyobcowanie egzystencji zostało pokonane. Zwycięstwo to dokonało się przez pośrednictwo zmartwychwstałego Chrystusa ${ }^{73}$.

Tym, co nieodłącznie wiąże się $\mathrm{z}$ interpretacją zbawczych wydarzeń śmierci i zmartwychwstania Chrystusa są koncepcje soteriologiczne czy też, mówiąc językiem Tillicha, doktryny pokuty (ang. atonement). Zbawienie płynące z wydarzeń paschalnych staje się bowiem integralną częścią teologii chrześcijańskiej i musi zostać ulokowane w jej systemie. Pełni ono dla tego systemu funkcję wręcz centralną. Niezwykle istotnym pytaniem teologicznym zawsze było pytanie o to, jak swoją śmiercią Pan Jezus dokonał zbawienia. W jaki sposób człowiek został zbawiony dzięki śmierci i zmartwychwstaniu Chrystusa? Choć soteriologia jest zasadniczym działem teologii, nie sposób znaleźć w niej takiej jednorodności i wyrazistości rozstrzygnięć jak choćby $\mathrm{w}$ trynitologii czy chrystologii ${ }^{74}$. W teologii od początku funkcjonowały różne koncepcje soteriologiczne i nie było tak, by Kościół zdecydował związać $\mathrm{z}$ jakimś konkretnym rozstrzygnięciem ${ }^{75}$. Tillich uważa, że ten pluralizm w soteriologii wynika $\mathrm{z}$ tego, że bardzo istotny jest

\footnotetext{
${ }^{72}$ Por. Tillich, Teologia systematyczna, t. 2, 149-154.

${ }^{73}$ Zmartwychwstanie Chrystusa ma oczywiście znaczenie nie tylko dla zbawienia jednostki, ale i dla całej historii świata, której jest przełomowym momentem. Por. Tillich, The New Being, 179.

${ }^{74}$ Por. O'Collins, Jezus nasz Odkupiciel, 1.

${ }^{75}$ Wydaje się dość jasne, że ów pluralizm wiąże się ostatecznie z pluralizmem antropologii. Wizja człowieka determinuje to, jak widzi się jego zbawienie. Por. Jacek Kempa, „Antropologiczne źródła pluralizmu w soteriologii chrześcijańskiej. O antropologicznych założeniach soteriologii Atanazego z Aleksandrii i Anzelma z Canterbury”, w: Antropologia miejscem spotkania i dialogu międzyreligijnego, red. Grzegorz Kucza, Grzegorz Wita (Katowice: Księgarnia Świętego Jacka, 2008), 144-163.
} 
w niej aspekt subiektywny ${ }^{76}$. Soteriologia jest ściśle związana z subiektywnym wymiarem, dlatego żadna obiektywizująca teoria nie może być dla niej rozstrzygająca. Pytanie o to, jak Chrystus zbawił człowieka, jest nieodłącznie związane z pytaniem o to, jak człowiek przyjmuje to zbawienie. Tillich w tym kluczu ocenia popularne teorie soteriologiczne, takie jak teoria okupu - będąca typowo obiektywną, lub subiektywizująca teoria Abelarda.

Jeśli zaś chodzi o poglądy samego Tillicha, teolog podaje kilka postulatów, które wyznaczają jego zdaniem tory dobrej doktryny zbawienia. Pierwsza zasada, która jest także pierwszą co do wagi, to zasada prymatu Boga $^{77}$. Głosi ona po prostu, że wyłącznie Bóg jest dawcą zbawienia. Druga zasada mówi, że nie ma w Bogu sprzeczności między miłością a sprawiedliwością ${ }^{78}$. Trzeci postulat głosi, że zbawienie nie jest lekceważeniem realności i głębi grzechu. Kolejna zasada mówi, że zbawcze dzieło Boga trzeba przede wszystkim rozumieć jako Jego uczestnictwo w egzystencjalnym wyobcowaniu. Piąta zasada dopowiada natomiast, że to uczestnictwo manifestuje się w krzyżu Chrystusa. Wreszcie zasada szósta mówi, że ludzie, uczestnicząc w Nowym Bycie, uczestniczą także w zbawczym akcie Boga ${ }^{79}$.

Podane przez Tillicha wskazania wydają się być zasadne i rozsądne, pokazując właściwą perspektywę dla soteriologii. I znów trzeba dostrzec, że Chrystus i Jego śmierć odgrywają tu rolę pośredniczącą. Przez krzyż Chrystusa Bóg wchodzi w warunki egzystencji i poddaje się im dla naszego zbawienia. Nie ma zatem zbawienia bez pośrednictwa Chrystusa. Teologia Tillicha potwierdza te fundamentalne dla chrześcijaństwa intuicje. Można jednak zarzucić teologowi, że nie przedstawia żadnej konkretnej teorii soteriologicznej. Tillich nie wyjaśnia precyzyjnie, co według niego oznacza, że Jezus umarł za ludzi i dla ich zbawienia. Wyznacza jedynie pewne zasady, którymi muszą się kierować zdrowe doktryny soteriologiczne, ale sam unika konstrukcji takiej doktryny. Jest to pewien minus i brak refleksji Tillicha, choć skądinąd może być to pewną wskazówką, by zachowywać więcej powściągliwości i ostrożności w wyjaśnianiu tak złożonej kwestii, jak zbawienny charakter wydarzenia śmierci Chrystusa.

\footnotetext{
${ }^{76}$ Por. Tillich, Teologia systematyczna, t. 2, 149.

${ }^{77}$ Por. ibid., 161.

${ }^{78}$ Por. ibid., 161-162; Tillich, The New Being, 30-33. Zasada ta wydaje się szczególnie istotna także dla rodzimej debaty teologicznej, choćby sporów związanych z tezami Wacława Hryniewicza. W dyskusjach o nadziei powszechnego zbawienia chodzi z pewnością przede wszystkim o obraz Boga. Por. Robert Rynkowski, Każdy jest teologiem. Nieakademicki wstęp do teologii (Kraków: Wydawnictwo WAM, 2012), 163.

${ }^{79}$ Por. Tillich, Teologia systematyczna, t. 2, 162-163.
} 
Poza swoimi ogólnymi wskazaniami i rozrachunkiem z klasycznymi koncepcjami soteriologicznymi Tillich omawia jeszcze trzy kluczowe pojęcia, które składają się na szkielet doktryny o zbawieniu. Są to: odrodzenie, usprawiedliwienie i uświęcenie. Kolejność jest tu jak najbardziej znacząca, pokazuje ona bowiem logiczny porządek zbawienia. Pierwszy etap polega po prostu na partycypacji w Nowym Bycie ${ }^{80}$. To właśnie uczestnictwo określa się mianem odrodzenia ${ }^{81}$. Sam termin „odrodzenie” może się kojarzyć z jakimś wewnętrznym przeżyciem, pewnym doświadczeniem religijnym, które jest przełomowe dla wierzącej osoby. Teolog jednak odżegnuje się od takiej optyki. Jego zdaniem wszelkie psychiczne doświadczenia mogą być jedynie skutkiem odrodzenia, ale nie są nim samym. Są więc one wtórne i ich obecność lub jej brak nie mogą być rozstrzygające. Termin „odrodzenie" ma oznaczać przede wszystkim, wbrew pozorom, obiektywny aspekt zbawienia. Chodzi o Nowy Byt, o nowy sposób życia, jaki zaczyna się w spotkaniu z Chrystusem. „Obiektywna rzeczywistość Nowego Bytu poprzedza subiektywną w nim partycypację" ${ }^{\prime 82}$. Mówiąc o odrodzeniu, mamy więc na myśli po prostu partycypację w nowym, zbawczym stanie rzeczy. Metafora nowych narodzin pomaga zrozumieć, że dzięki dziełu Chrystusa rozpoczyna się zupełnie nowe stadium rzeczywistości.

Drugim pojęciem, które oddaje pewien aspekt zbawczego misterium dokonanego przez Jezusa Chrystusa, jest usprawiedliwienie ${ }^{83}$. Jest to termin szczególnie istotny w kontekście tradycji luterańskiej, reprezentowanej przez omawianego twórcę. W czasach rozwoju reformacji i w kolejnych wiekach dyskusji między protestantami a katolikami szczególnie istotne znaczenie miało właśnie pojęcie i doktryna usprawiedliwienia. Aby człowiek rzeczywiście doświadczył mocy usprawiedliwienia, musi je przyjąć w wierze. Tak należy rozumieć, zdaniem Tillicha, formułę „usprawiedliwienie z łaski przez wiarę", którą często niezbyt szczęśliwie skraca się do „usprawiedliwienie z wiary" ${ }^{\prime}$. Tillich podkreśla, idąc za tradycją luterańską, że nie wolno tej formuły rozumieć tak, jakoby wiara była jakąś zasługą człowieka, dzięki której otrzyma on od Boga usprawiedliwienie. Nie, Bóg bez żadnych zasług człowieka czyni go sprawiedliwym przez krzyż i zmartwychwstanie Chrystusa. Słowo usprawiedliwienie to właśnie przede wszystkim oznacza -

\footnotetext{
${ }^{80}$ Por. Tillich, Teologia systematyczna, t. 2, 164.

${ }^{81}$ Od strony bardziej filozoficznej Tillich pisze tak: „Męstwo bycia jako część całości jest męstwem afirmowania swego bytu przez uczestnictwo". Tillich, Męstwo bycia, 108.

${ }^{82}$ Tillich, Teologia systematyczna, t. 2, 164.

${ }^{83}$ Por. ibid., 165-166.

${ }^{84}$ Por. ibid., 166.
} 
że Bóg czyni człowieka na powrót sprawiedliwym, choć ten na to nie zasłużył. Człowiek ma dostęp do usprawiedliwienia przez wiarę $\mathrm{w}$ tym sensie, że musi uwierzyć, iż rzeczywiście jest usprawiedliwiony. Wątek ten Tillich analizuje $\mathrm{w}$ wielu miejscach swojego teologicznego dzieła, podkreślając przy tym, że formułę o usprawiedliwieniu można by współczesnym językiem wyrazić następująco: zaakceptowanie tego, że jest się zaakceptowanym ${ }^{85}$. Mówiąc dokładniej, chodzi o to, by zaakceptować Bożą akceptację mimo swej nieakceptowalności ${ }^{86}$. Choć człowiek nie jest godzien tego, by być uznanym za sprawiedliwego, Bóg go takim czyni i za takiego go uznaje. W gestii człowieka pozostaje tylko to, by to uznanie $\operatorname{przyjąc~}^{87}$.

Ostatnim elementem doktryny o zbawieniu jest według Tillicha uświęcenie $^{88}$. Autor poświęca mu najmniej uwagi. W zasadzie znaczeniowo uświęcenie nie różni się $\mathrm{w}$ sposób wyraźny od dwóch poprzednich pojęć. Tym samym Tillich podąża śladem klasycznej myśli luterańskiej i myśli samego Lutra, dla którego usprawiedliwienie jest priorytetowe względem uświęcenia. To drugie pojęcie wskazuje na proces, który dokonuje się w życiu chrześcijańskim dzięki odrodzeniu i usprawiedliwieniu. Można powiedzieć, że uświęcenie to pewna droga pogłębiania, coraz mocniejszego wchodzenia w rzeczywistość odrodzenia, usprawiedliwienia, Nowego Bytu. Podmiotem aktywnym w procesie uświęcania człowieka jest Duch Święty.

\section{ZAKOŃCZENIE}

Podsumowując, trzeba powiedzieć, że Paul Tillich w swojej wizji soteriologicznej pozostaje teologiem pośrednictwa. Jego chrystologia jest podporządkowana perspektywie zbawczej, jest niejako poddana soteriologii. Mówiąc o Chrystusie, Tillich mówi przede wszystkim o misterium zbawienia człowieka. Podmiotem zbawienia jest Bóg, który w Chrystusie objawia się

\footnotetext{
${ }^{85} \mathrm{~W}$ jednym z kazań pastor Tillich powie: „Nie pytaj o imię, możliwe, że go później znajdziesz. Nie próbuj teraz coś czynić, możliwe, że później uczynisz bardzo dużo. Nie ubiegaj się o nic, nie wymuszaj niczego, nie zamierzaj niczego. Zaakceptuj tylko to, że jesteś zaakceptowany. Kiedy nam się to przydarza, wtedy doświadczamy tego, czym jest łaska”. Tillich, Prawda jest $w$ głębi, 141.

${ }^{86}$ Por. Tillich, Męstwo bycia, 170.

${ }^{87}$ Ponadto tylko przyjmując tę akceptację człowiek jest w stanie zaakceptować samego siebie. Por. Tillich, The New Being, 12.

${ }^{88}$ Por. Tillich, Teologia systematyczna, t. 2, 166-167.
} 
w całej pełni. Zbawicielem człowieka jest Jezus jako Chrystus, nie zaś Jezus jako postać wyłącznie historyczna. Nie sposób jednak uznawać realność tego zbawienia, jeśli nie uzna się także, że Jezus rzeczywiście żył dwa tysiące lat temu. Teologia Tillicha przypomina, że choć wiara nie może się opierać na badaniach historycznych dotyczących początków chrześcijaństwa, to nie może także być czymś zupełnie ahistorycznym, nie może pomijać realności Jezusa.

Postawienie w centrum teologicznego systemu osoby Jezusa Chrystusa i ukazanie jej jako pośrednika zbawienia sprawia, że Tillich dobrze wpisuje się swoją refleksją w tradycję luterańską. Zbawcze pośrednictwo Chrystusa stanowi u tego myśliciela pewną oś całej teologii, nawet jeśli sam termin „pośrednictwo” nie pojawia się zbyt często. To w Chrystusie Nieuwarunkowane zakorzenia się $\mathrm{w}$ uwarunkowanej rzeczywistości, to przez Niego Bóg ocala świat. Tylko przez Chrystusa, Jego czyny, słowa, mękę, śmierć i zmartwychwstanie, ludzie otrzymują pełnię objawiania i zbawienia. Można więc powiedzieć, że Tillich podtrzymuje tradycyjną optykę solus Christus.

Zbawcze pośrednictwo Chrystusa jawi się w myśli Tillicha jako pochodzące $\mathrm{z}$ woli samego Boga. Jest to pośrednictwo wpisane w ekonomię zbawienia, w Boży plan. W ten sposób autentyczne pośrednictwo zawsze jest darem Bożym dla człowieka, któremu Bóg chce się objawiać i którego chce zbawiać. W świetle myśli Tillicha widać wyraźnie, że trzeba odróżniać ludzkie konstrukty religijne, często nabudowane na grzechu, wyobcowaniu i lęku przed Bogiem, od autentycznego pośrednictwa, które pochodzi od samego Boga.

Zasada solus Christus, rozwijana przez Tillicha, nie musi wykluczać szeregu innych pośrednictw. W samej teologii Tillicha mowa jest choćby o pośrednictwie świata przyrody, pośrednictwie sakramentów czy Kościoła. Każde pośrednictwo trzeba jednak widzieć jako pośrednictwo nie obok, lecz $w$ Chrystusie. Zasadę solus Christus warto rozumieć nie jako bezwzględną, lecz jako inkluzywną. Słowa i czyny Chrystusa same są dla nas dziś zapośredniczone, choćby w Biblii, w głoszeniu Ewangelii, w sakramentalnych znakach. Tym samym także i Kościół ma swój udział w pośrednictwie Chrystusa, jest w nie włączony. Otwarte rozumienie zasady solus Christus jest ważne zwłaszcza $\mathrm{z}$ ekumenicznego punktu widzenia, ponieważ temat pośrednictwa i pośredników jest jednym z punktów dyskusyjnych w relacjach katolicko-protestanckich.

Teologia pośrednictwa w ujęciu Tillicha dobrze wpisuje się w tradycję myśli chrześcijańskiej, zwłaszcza luterańskiej. Jej nowość polega natomiast 
na zastosowaniu współczesnych kategorii i pojęć, często związanych z filozofią egzystencjalną. Chodzi o takie pojęcia, jak: Nowy Byt, wyobcowanie, troska ostateczna czy akceptacja. Tym samym Tillich, konstruując swój system teologiczny, pozwala wybrzmieć tradycyjnym tematom i tezom w sposób świeży i komunikatywny. Nawet jeśli terminologia proponowana przez Tillicha nie dla wszystkich jest przekonująca, to myśl niemiecko-amerykańskiego teologa zachęca do tego, by na klasyczne zagadnienia teologiczne spojrzeć w nowym kontekście intelektualnym i szukać nowych środków wyrazu dla chrześcijańskich prawd.

\section{REFERENCJE}

Barth, Grzegorz. Hermeneutyka osoby. Lublin: Wydawnictwo KUL, 2013.

Bonhoeffer, Dietrich. Wybór pism. Tłum. Anna Morawska. Warszawa: Więź, 1970.

Bultmann Rudolf, Karl Jaspers. Problem demitologizacji. Tłum. Dawid Kolasa, Tomasz Kupś i Maciej Pawlicki. Torun: Wydawnictwo Naukowe UMK, 2015.

Ehrman, Bart. Did Jesus Exist? The Historical Argument for Jesus of Nazareth. San Francisco: HarperCollins, 2012.

Hamilton, Kenneth. The System and the Gospel. Michigan: Macmillan, 1963.

Kempa, Jacek. „Antropologiczne źródła pluralizmu w soteriologii chrześcijańskiej. O antropologicznych założeniach soteriologii Atanazego z Aleksandrii i Anzelma z Canterbury". W: Antropologia miejscem spotkania i dialogu międzyreligijnego, red. Grzegorz Kucza i Grzegorz Wita, 144-163. Katowice: Księgarnia Świętego Jacka, 2008.

Kempis, Tomasz. O naśladowaniu Chrystusa. Tłum. Anna Kamieńska. Warszawa: PAX, 1980.

Kudasiewicz Józef, Henryk Witczyk. Jezus i Ewangelie w ogniu dyskusji. Od H. Reimarusa do T. Polaka. Kielce: Instytut Teologii Biblijnej Verbum, 2011.

Kudasiewicz, Józef. Jezus historii a Chrystus wiary. Lublin: Redakcja Wydawnictw KUL, 1987.

Meier, John P. A Marginal Jew. Rethinking the Historical Jesus. T. 1. New York: Doubleday, 1991.

O’Collins, Gerald. Jezus nasz Odkupiciel. Chrześcijańskie ujęcie zbawienia. Tłum. Jan Pociej. Kraków: Wydawnictwo UJ, 2009.

Reijnen, Anne Marie. „Tillich's Christology”. W: The Cambridge Companion to Paul Tillich, red. Russell Re Manning, 56-73. Cambridge: Cambridge University Press, 2009.

Rusecki, Marian. Pan zmartwychwstat $i$ żyje. Zarys teologii rezurekcyjnej. Warszawa: PAX, 2006.

Rynkowski, Robert. Każdy jest teologiem. Nieakademicki wstęp do teologii. Kraków: Wydawnictwo Naukowe WAM, 2012.

Smith, Dwight M. Jr. „The Historical Jesus in Paul Tillich's Christology”. The Journal of Religion 46, nr 1 (1966): 131-147.

Strzelczyk, Grzegorz. „Bezgrzeszność Jezusa jako problem współczesnej chrystologii systematycznej”. Ślaskie Studia Historyczno-Teologiczne 42, nr 2 (2009): 49-58. 
Tavard, George H. Paul Tillich and the Christian Message. New York: Scribner, 1962.

Tillich, Paul. „A Reinterpretation of the Doctrine of the Incarnation”. W: Main Works / Hauptwerke. VI, red. Gert Hummel, 305-318. Berlin / New York: De Gruyter, 1992.

Tillich, Paul. „Redemption in Cosmic and Social History”. W: Main Works / Hauptwerke. VI, red. Gert Hummel, 273-284. Berlin / New York: De Gruyter, 1992.

Tillich, Paul. Dynamika wiary. Tłum. Adam Szostkiewicz. Poznań: W Drodze, 1987.

Tillich, Paul. Prawda jest w głębi. Tłum. Jan Adrian Łata. Wrocław / Oleśnica: Signum, 1996.

Tillich, Paul. Teologia systematyczna. Tłum. Józef Marzęcki. T. 2. Kęty: Antyk, 2004.

Tillich, Paul. The New Being. New York: Charles Scribner's Sons, 1955.

Zadykowicz, Tadeusz. Sequela Christi et imitatio hominis. Paradygmat naśladowania we wspótczesnej refleksji teologiczno moralnej. Źródła i perspektywy. Lublin: Wydawnictwo KUL, 2011.

\section{ZBAWCZE POŚREDNICTWO CHRYSTUSA W MYŚLI PAULA TILLICHA}

\section{Streszczenie}

Zagadnienie zbawczego pośrednictwa Chrystusa jest jednym z kluczowych dla teologii dogmatycznej. Jednym z myślicieli, który w czasach współczesnych przedstawił oryginalną koncepcję soteriologiczną, był Paul Tillich. Niniejszy artykuł przedstawia jego teorię. W pierwszym kroku ukazane zostają poglądy Tillicha na kwestię Jezusa historycznego. Następnie przedstawiona jest właściwa koncepcja zbawienia jako zwycięstwa nad warunkami egzystencji. Wreszcie omówiono zagadnienie pośrednictwa zbawczego w wydarzeniach paschalnych. Zaprezentowane analizy prowadzą do wniosku, że nie da się oddzielić chrystologii od soteriologii, a także nie da się uprawiać teologii bez operowania kategorią pośrednictwa.

Słowa kluczowe: Paul Tillich; chrystologia; pośrednictwo; soteriologia; Jezus historyczny. 